\title{
Rural Tourism in Malaysia: A Homestay Program
}

\author{
Yusnita Yusof, Mohd Shaladdin Muda, Wan Aziz Amin \\ Universiti Malaysia Terengganu, Kuala Terengganu, Terengganu, Malaysia \\ Yahaya Ibrahim \\ Universiti Sultan Zainal Abidin, Kuala Terengganu, Terengganu, Malaysia
}

\begin{abstract}
Rural tourism has been recognized as an effective catalyst of rural socio-economic redevelopment in many countries. The rise of the rural tourism development was partly due to the increase demand from tourists who want to enjoy natural environment which available in rural setting and cultural heritage which still preserved by local folks. This paper is intended to explore the concept of rural tourism and homestay program establishment in Malaysia in terms of its development, planning, and promotional efforts. Malaysia has embraced rural tourism in an effort to upgrade the economic regeneration in rural areas through tourism activities and products offering. Priorities for the economic upgrading of rural tourism has been given attention in the Ninth Malaysia Plan (2006-2010) and Tenth Malaysia Plan (2011-2015) to reduce poverty among rural communities. One of the rural cultural tourism products is homestay establishment managed by rural local community. This conceptual paper will provide a review of literature consisting of the background, planning, development, and current situation of homestay program as rural tourism product. The homestay program is said to have increase additional household income and promote better awareness for the continued conservation of cultural heritage. Majority of the rural communities involved in tourism to gain its economic benefits since theoretically an increase in income gained from tourism activities will improve their quality of life. The objectives of the paper are to understand the current scenario of rural tourism development in Malaysia particularly homestay program, and to analyse its challenges and issues pertaining to homestay management. The future implications of the research could be the re-assessment of rural tourism policy towards local community, and marketing efforts by tourism key players and related government agencies to upgrade this rural tourism product.
\end{abstract}

Keywords: rural tourism, homestay program, rural community, quality of life, government, Malaysia

\section{Rural Tourism}

Rural areas are often quite far from the city center and may be marginalized from the mainstream development as the result of the geographical setting which situated in countryside, and equipped with less basic facilities such as roads, communication and transport facilities. The small number of population also becomes one of the factors which make rural area difficult to grow and develop due to lack of manpower (Malaysia Ministry of Finance, 2010). Traditional jobs were still involving farming and poultry based activities

Yusnita Yusof, Lecturer, Ph.D. candidate, Faculty of Management and Economics, Universiti Malaysia Terengganu.

Mohd Shaladdin Muda, Dean, Professor, Ph.D., Faculty of Management and Economics, Universiti Malaysia Terengganu.

Wan Aziz Amin, Director, Associate Professor, Ph.D., Centre for Academic Excellence, Universiti Malaysia Terengganu.

Yahaya Ibrahim, Vice Chancellor, Professor, Ph.D., Vice Chancellor Office, Universiti Sultan Zainal Abidin.

Correspondence concerning this article should be addressed to Yusnita Yusof, Faculty of Management and Economics, Universiti Malaysia Terengganu, 21030 Kuala Terengganu, Terengganu, Malaysia. E-mail: yusnitayusof@umt.edu.my. 
to be consumed only by the farmers and their extended families. Liu (2006) stated that rural economic development was still constrained by underdevelopment and remoteness, and local community relies heavily on income from agricultural sources to meet their daily needs.

Therefore, to boost economic development in the rural area, rural communities need to find an alternative to the use of existing resources to increase their income (Cawley \& Gillmore, 2008; Liu, 2006). Tourism is said to be a development tool that can help improve economic development in rural areas by offering tourist destinations and other ancillary services such as accommodation, sale of handicrafts, food stalls and restaurants creation, and other related tourist services (Liu, 2006; Su, 2011). Rural tourism boosts local community ability and chances to participate in tourism industry. Rural tourism has been recognized as a catalyst for rural development through tourism activities such as accommodation establishment, provision of food and beverages, selling handy craft, providing services, e.g., hiking guidance, boat equipment supplies, and related rural activities (Crawley \& Gillmore, 2008; Saxena \& Ilbery, 2008).

Any tourism activities taken place in rural area are considered rural tourism, and a sustainable rural development primarily focus on activities taking place in rural settings starting from agriculture activities (Chiritescu, 2011). Rural tourism concept may include among others farming activities, nature sightseeing, sporting and adventure activities, health and spa, education, folklore heritage and arts, local cultures, values, beliefs and lifestyle (Su, 2011). However, according to Cawley and Gillmore (2008) based on the economic development of tourism remains a problem, particularly when it involves a variety of sources and stakeholders. Rural tourism also facing a few problems such as the reduction of wages for hiring unskilled workers who originated from the rural area and employment status is temporary and seasonal (Fleischer \& Felsenstein, 2000). According to them, although rural tourism is said to be an instrument of economic development in rural areas it is still not fully strengthened. Nevertheless, the government often insists that rural tourism is the option for development strategies that can help village communities for additional source of income through tourism activities. This paper will explore the concept of rural tourism and homestay program establishment in Malaysia as part of the rural tourism product. This paper also intended to briefly review the current development of homestay program.

\section{Rural Tourism in Malaysia}

Tourism plays an important role in the economic growth of a country. According to the United Nations World Tourism Organisation (UNWTO) tourism sector growing steadily ever since the 1950's and has gone through a phase of better product mix to become one of the fastest-growing economic sector worldwide, with revenue of USD919 billion in 2010, in line with the increase in the existence of a new tourist destinations, particularly in developing countries (UNWTO, 2011). Tourism contributes to the creation of employment opportunities and plays an important role in reducing poverty and raising awareness of sustainable environment.

In the context of Malaysia's economy, tourism is the second largest industry contributing to the country after manufacturing industry, totaling RM56.5 billion in terms of foreign tourist arrivals of 24.6 million people in 2010 (Tourism Malaysia, 2011). This amount represents an increase of $31 \%$ on income countries than in 2009. Recent data by the World Travel \& Tourism Council (WTTC) indicates that the tourism industry contributed 14.8\% to the Gross Domestic Product (GDP) of Malaysian economy which worth RM125.4 billion and generated 1.6 million jobs, which accounted for nearly $13 \%$ of the total workforce in Malaysia (World Travel \& Tourism Council, 2012). The increase number of foreign tourist arrivals since year 1998 has proved that Malaysia is 
successes in boosting tourism economy as shown in Table 1. From only 5.5 million tourists in 1998, Malaysia has welcomed 24.6 million tourists in the year 2010, an increasing of $77 \%$ in the last decade.

Table 1

Foreign Tourist Arrivals and Tourism Revenue in Malaysia

\begin{tabular}{lll}
\hline Year & Arrivals (million) & Revenue (RM billion) \\
\hline 2010 & 24.6 & 56.5 \\
2009 & 23.6 & 53.4 \\
2008 & 22.0 & 49.6 \\
2007 & 20.9 & 46.1 \\
2006 & 17.4 & 36.3 \\
2005 & 16.4 & 32.0 \\
2004 & 15.7 & 29.7 \\
2003 & 10.5 & 21.3 \\
2002 & 13.2 & 25.8 \\
2001 & 12.7 & 24.2 \\
2000 & 10.2 & 17.3 \\
1999 & 7.9 & 12.3 \\
1998 & 5.5 & 8.6 \\
\hline
\end{tabular}

Note. Source: Tourism Malaysia (2011).

The government is optimistic about the growth of the tourism sector in Malaysia. In one of the articles on economic development in Malaysia, written by the former Prime Minister of Malaysia, Tun Abdul Razak Hussein in 1973, he expressed a desire and strong determination of the government at that time for the success of the tourism sector despite the anticipation of this industry which lamented that Malaysia could not compete with its neighbors and not much profit to be derived (Hussein, 1973). But the expectation was totally dejected because the tourism industry in Malaysia is constantly evolving to this day. The government has focusing and intensifying their efforts that can be seen through the increase in the budget allocation for development of the tourism industry in Budget 2011 and 2012 respectively (Prime Minister's Office, 2011a, 2011b). Government also emphasizes the local community, particularly in rural areas to participate and equally involved in the tourism industry in order to enjoy these attractive economic returns which would increase their household income. Priority to upgrade the rural tourism economy has been addressed in the Ninth Malaysia Plan for year 2006 to 2010, to reduce poverty among the rural and urban communities (Ibrahim \& Razzaq, 2010). National Tourism Policy was issued by the Ministry of Tourism Malaysia (2011), namely, to make the tourism industry as one of the primary sector, sustainable, viable and quality in contributing to national development policy which emphasizes one of the objectives, i.e., to empower rural communities through rural tourism activities.

The government also focus on the development of rural tourism as a major contributor in promoting eco-tourism which is the current trend in their efforts to tourism sustainability remains a key focus of the government under the 10th Malaysia Plan for the year 2011 to 2015 (Economic Planning Unit, 2010). Awareness about the importance of developing rural tourism is based on natural tourism product offerings in rural areas such as eco-tourism, agro-tourism, history, heritage and culture and the environment that have not been fully contaminated (Ibrahim \& Hassan, 2011; MacDonald \& Jolliffe, 2003). According to Loganathan and Ibrahim (2010) a total of $15 \%$ of foreign tourists came to Malaysia chose to live in rural areas. This means that there is a relatively high demand from tourists to enjoy the natural and cultural heritage in the countryside, and this 
opportunity should be seized by the tour operators to concentrate their tourism activities in the rural area. Siow et al. (2011) stated that rural tourism in Malaysia has a growth rate of 30\% each year and they further claimed that Malaysia is popular as rural tourism destination among international tourists.

\section{Homestay Program as Rural Tourism Product}

The issue of poverty in rural communities is still plaguing the government in an effort to achieve developed nation status by 2020. To address the issues which affecting the well-being of the people, poverty has become one of the main issues of concern by the government in Budget 2011 under one of the four pillars of national transformation of the Government Transformation Program (GTP) which focuses on six National Key Result Areas (NKRA) as well as crime, corruption, education, rural basic infrastructure, and public transport (Malaysia Ministry of Finance, 2010). In addition to offset the increase in income and living standards between urban-rural as to not marginalized from the mainstream of development, rural poverty development program involves huge government expenditure each year. Based on the 2010 Budget, government continues to provide for the eradication of extreme poverty and the rural poor, a total of RM877 million which has been spent through various assistance programs such as welfare assistance given to help poor households on the first day of each month and so forth.

Among the issues and challenges of poor rural communities is that most of them have low skill levels, the opportunity to generate income is limited, and the issue of the migration of young people to urban areas in search of work has resulted in a labor shortage in rural areas (Malaysia Ministry of Finance, 2010). Some rural areas are still lacking of basic infrastructure such as the provision of 24-hour electricity supply is still limited and often distracted; lack of clean water or treated water; as well as a network of inadequate road system has also resulted in the development gap between rural-urban areas. Community involvement in community-based tourism has been given attention by the government as one of the implementation strategies for helping the poor, particularly in rural areas to the development and participation in the tourism sector in the country (Kayat, Mohdnor, \& Idris, 2006). Many local communities are aware of the advantages of the tourism industry, which could provide opportunities for them to improve their economic status and create awareness about the importance of environmental preservation. One of the community-based tourism approaches for rural communities practiced in Malaysia is through the homestay program.

Homestay program began informally since the 1970s with some involvement of the local community who provide accommodation in their own homes to foreign tourists by charging a very minimal price compared to hotels or resorts (Hamzah, 2008; Kayat, 2010; Ibrahim \& Razzaq, 2010). Such accommodation sector is also known by various terms such as farm stay, culture homestay, heritage homestay, education homestay, voluntary homestay, private accommodation, leisure stay, and cottage (Albaladejo-Pina \& Diaz-Delfa, 2009; Barnett, 2001; Gu \& Wong, 2006; Pearce, 1990). Success after success had been proclaimed by the government as a result of the government's effort to promote the homestay program and the involvement of local communities in organizing it. Homestay program is said to have given a return in terms of household income which reach thousands of dollars, and local communities continue to promote awareness of cultural heritage conservation. Until December 2011, there were 3,211 homestay operators involving 236 villages participate in homestay program as showed in Table 2. 
Table 2

\begin{tabular}{|c|c|c|c|c|c|}
\hline No. & State & No. of homestays & No. of villages & No. of operators & No. of rooms \\
\hline 1 & Perlis & 3 & 3 & 56 & 64 \\
\hline 2 & Kedah & 14 & 19 & 296 & 393 \\
\hline 3 & Pulau Pinang & 9 & 9 & 200 & 227 \\
\hline 4 & Perak & 6 & 30 & 231 & 308 \\
\hline 5 & Selangor & 15 & 18 & 458 & 660 \\
\hline 6 & Melaka & 7 & 7 & 115 & 173 \\
\hline 7 & Negeri Sembilan & 9 & 27 & 231 & 354 \\
\hline 8 & Johor & 16 & 35 & 478 & 623 \\
\hline 9 & Kelantan & 6 & 7 & 133 & 133 \\
\hline 10 & Terengganu & 6 & 6 & 104 & 106 \\
\hline 11 & Pahang & 14 & 19 & 249 & 376 \\
\hline 12 & Sarawak & 26 & 28 & 353 & 357 \\
\hline 13 & Sabah & 16 & 25 & 228 & 438 \\
\hline \multirow[t]{2}{*}{14} & Labuan & 3 & 3 & 79 & 97 \\
\hline & Total & 150 & 236 & 3,211 & 4,309 \\
\hline
\end{tabular}

The participation of homestay program operators in rural tourism activities in Malaysia is one of the government's ongoing efforts to develop rural tourism in order to achieve the target of reducing economic disparities of rural and urban as well as empowering the village community. Based on this understanding, a few of the local communities responded to the challenge with a homestay program that allows foreign tourists and domestic tourists alike to stay together with the local community and be able to learn their way of life, culture and daily practices of the community (Ibrahim \& Razzaq, 2010). Homestay program was officially positioned as community-based tourism programs in Malaysia in 1995 in the village of Desa Murni, Temerloh, Pahang which has become one of the successful homestay programs and a pilot program at that time. Since then, the government has given special attention in terms of additional funds for improvements, marketing and development of more homestay program in Malaysia. The majority of local communities involved in homestay to gain additional income (Kayat, 2010).

\section{Conclusions}

Many agreed that homestay has indeed improved the livelihood of the operators in terms of economic and social status (Hamzah, 2008; Ibrahim \& Razzaq, 2010; Ismail, Muhammad, \& Alwi, 2007; Kayat, 2011). Since the homestay program is considered quite successful in Malaysia, various parties are keen and show support for the program. Various efforts have been undertaken by the government in developing the homestay program including provide development funds and improve infrastructure facilities in rural areas.

Still, there is room for improvement in this aspect that will be driven by the leadership of rural communities themselves with the help of the private sector in increasing the activity of marketing and promotion so that more tourists come to their homestay. This is because that there is a high demand from foreign tourists who prefer the rural areas as their tourist destinations. The local communities and private sectors must take the opportunity to leverage their existing capabilities so that they can market their products in accordance with the traveler needs. It is hope that all parties including government bodies, local communities, and private tourism players can collaborate on all aspects of marketing strategies so that they can reach the desired target market. 
The future implications of the research could be the re-assessment of rural tourism policy towards local community, and marketing efforts by tourism key players such as travel agencies, tour operators, and marketing bodies to maximize the marketing strategies targeting the correct market. This synergy should be done through collaboration within various agencies including government, local community, and private sector to upgrade this rural tourism product for better positioning in tourism industry.

\section{References}

Albaladejo-Pina, I. P., \& Diaz-Delfa, M. T. (2009). Tourist preferences for rural house stays: Evidence from discrete choice modelling in Spain. Tourism Management, 30(6), 805-811.

Barnett, S. (2001). Manaakitanga: Maori hospitality-A case study of Maori accommodation providers. Tourism Management, 22, 83-92.

Cawley, M., \& Gillmor, D. A. (2008). Integrated rural tourism: Concepts and practice. Annals of Tourism Research, 35(2), 316-337.

Chiritescu, V. (2011). Sustainable rural development in Romania-Needs and priority objectives. Agricultural Economics and Rural Development, 1(1), 147-160.

Economic Planning Unit. (2010). Tenth Malaysia plan 2011-2015. Putrajaya: Jabatan Perdana Menteri.

Fleischer, A., \& Felsenstein, D. (2000). Support for rural tourism: Does it make a difference? Annals of Tourism Research, 27(4), 1007-1024.

Gu, M., \& Wong, P. P. (2006). Residents’ perception of tourism impacts: A case study of homestay operators in Dachangshan Dao, North-East China. Tourism Geographies, 8(3), 253-273.

Hamzah, A. (2008). Malaysian homestays from the perspective of young Japanese tourists: The quest for Furusato. Asian tourism: Growth and change (pp. 193-207). Amsterdam: Elsevier.

Hussein, A. R. (1973). Malaysia adjusts to the enlarged community. World Development, 1(7), 34-49.

Ibrahim, Y., \& Hassan, M. S. (2011). Tourism management at Taman Negara (National Park), Pahang, Malaysia: Conflict and synergy. Journal of Ritsumeikan Social Sciences and Humanities, 3, 109-122.

Ibrahim, Y., \& Razzaq, A. R. (2010). Homestay program and rural community development in Malaysia. Journal of Ritsumeikan Social Sciences and Humanities, 2, 7-24.

Ismail, I. L., Muhammad, R., \& Alwi, N. (2007). Peningkatan taraf hidup masyarakat luar bandar melalui program homestay di perkampungan komuniti nelayan sekitar daerah di Terengganu. Serdang, Proceeding at Seminar Kebangsaan Sains Sosial (pp. 324-337), UPM.

Kayat, K. (2010). The nature of cultural contribution of a community-based homestay programme. Tourismos: An International Multidisciplinary Journal of Tourism, 5(2), 145-159.

Kayat, K. (2011). Homestay programme as a Malaysian tourism product. Sintok: Universiti Utara Malaysia Press.

Kayat, K., Mohdnor, N. A., \& Idris, M. A. (2006). Kemahiran keusahawanan dan keperluannya dalam pembangunan homestay: Implikasi terhadap polisi pelancongan. Keusahawanan pelancongan: Potensi dan isu-isu semasa (pp. 109-119). Sintok (Kedah): Penerbit Universiti Utara Malaysia.

Liu, A. (2006). Tourism in rural areas: Kedah, Malaysia. Tourism Management, 27(5), 878-889.

Loganathan, N., \& Ibrahim, Y. (2010). Forecasting international tourism demand in Malaysia using Box Jenkins Sarima Application. South Asian Journal of Tourism and Heritage, 3(2), 50-60.

MacDonald, R., \& Jolliffe, L. (2003). Cultural rural tourism: Evidence from Canada. Annals of Tourism Research, 30(2), 307-322.

Malaysia Ministry of Finance. (2010). Economic Report 2010/2011. Kuala Lumpur: Percetakan Nasional Malaysia Berhad.

Malaysia Ministry of Tourism. (2011). Ministry policy. Retrieved from http://www.motour.gov.my/bm/profil-kementerian/dasar-kementerian.html

Park, D. B., \& Yoon, Y. S. (2011). Developing sustainable rural tourism evaluation indicators. International Journal of Tourism Research, 13(5), 401-415.

Pearce, P. L. (1990). Farm tourism in New Zealand: A social situation analysis. Annals of Tourism Research, 17, $337-352$.

Prime Minister's Office (2011b). Budget speech 2012. Retrieved from http://www.pmo.gov.my/dokumenattached/speech/files/Belanjawan2012.pdf 
Prime Minister’s Office. (2011a). Budget speech 2011. Retrieved from http://www.pmo.gov.my/bajet2011/Bajet2011.pdf Saxena, G., \& Ilbery, B. (2008). Integrated rural tourism: A border case study. Annals of Tourism Research, 35(1), $233-254$.

Siow, M. L. et al. (2011). Developing criteria and indicators for responsible rural tourism in Taman Negara National Park (TNNP), Malaysia. The Malaysian Forrester, 74(2), 143-156.

Su, B. (2011). Rural tourism in China. Tourism Management, 32(6), 1438-1441.

Tourism Malaysia. (2011). Facts and figures: Tourists arrivals and receipts to Malaysia. Retrieved from http://corporate.tourism.gov.my/research.asp

UNWTO. (2011). UNWTO Tourism highlights 2011 edition. Retrieved from http://mkt.unwto.org/sites/all/files/docpdf/unwtohighlights11enhr_1.pdf

World Travel \& Tourism Council. (2012). Travel \& tourism economic impact 2012: Malaysia. London: WTTC. 